\title{
THE EFFECT OF PERIOPERATIVE ANALGESIC DRUGS OMNOPON AND DEXKETOPROFEN ON THE FUNCTIONAL ACTIVITY OF IMMUNE CELLS IN MURINE MODEL OF TUMOR SURGERY
}

\author{
R. I. SYDOR ${ }^{1,2}$, N. M. KHRANOVSKA ${ }^{1}$, O. V. SKACHKOVA ${ }^{1}$, L. M. SKIVKA ${ }^{2}$ \\ ${ }^{1}$ National Cancer Institute, Ministry of Public Health of Ukraine, Kyiv, Ukraine; \\ ${ }^{2}$ Taras Shevchenko National University of Kyiv, Ukraine; \\ e-mail: creatogen@gmail.com
}

\begin{abstract}
We aimed to investigate the effect of perioperative analgesia with nonselective cyclooxygenase-2 inhibitor dexketoprofen and opioid drug omnopon on the functional activity of immune cells in tumor excision murine model. Lewis lung carcinoma cells were transplanted into hind paw of C57/black mice. On the $23^{\text {th }}$ day tumor was removed. Analgesic drugs were injected $30 \mathrm{~min}$ before and once a day for 3 days after the surgery. Biological material was obtained a day before, 1 day and 3 days after the tumor removal. IFN- $\gamma$, IL4, IL-10 and TGF- $\beta$ mRNA levels in splenic cells were assessed by quantitative real-time RT-PCR. Cytotoxic activity of splenocytes was estimated by flow cytometry. We found that in splenocytes of mice received opioid analgesia IL-10 mRNA level was increased 2.3 times on day one after the surgery compared to preoperative level $(P<0.05)$, while in dexketoprofen group this parameter did not change. IFN- $\gamma$ gene expression level on day 3 after tumor removal was $40 \%$ higher in splenocytes of dexketoprofen treated mice as compared with omnopon treated animals $(P<0.05)$. Cytotoxic activity of splenocytes on day 3 postsurgery was $(62.2 \pm 2.4) \%$ in dexketoprofen against $(50.2 \pm 3.3) \%$ in omnopon group. In conclusion, perioperative analgesia with cyclooxygenase inhibitor dexketoprofen in contrast to opioid analgesia with omnopon preserves higher functional activity of murine immune cells in the experimental model of tumor surgery.
\end{abstract}

Key words: omnopon, dexketoprofen, cyclooxygenase-2 inhibitor, immune cells, tumor surgery.

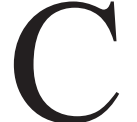
ancer is a leading cause of morbidity and mortality. Surgical resection of primary tumors is a common therapy for cancer, however, mortality from metastasis remains high. Clinical and experimental studies have shown that surgical stress factors, including tissue trauma, pain, anesthetic drugs and opioids, markedly affect the immune system, including both the specific and the non-specific immune response, thus creating conditions for tumor immune-evasion $[1,2]$.

Opioid pharmacotherapy are often used for the treatment of surgical and cancer pain, however, recent studies suggest the possibility that they might influence the rate of disease-free survival after tumor resection [3]. Acute and chronic opioid administration is known to have inhibitory effects on antibody production, natural killer cell activity, cytokine expression, and phagocytic activity [3, 4]. In recent years cyclooxygenase-2 (COX-2) inhibitors are actively studied as a new analgesic drugs which can substitute opioids or reduce their dose. COX-2 inhibitors are particularly interesting as analgesics for cancer surgery, as there is a growing body of evidence about their influence on cancer incidence $[5,6]$.

Despite a number of studies dedicated to comparison of antinociceptive effect of COX-2 inhibitors and opioids on murine models, there are limited data on tumor surgery models. Thus, we aimed to investigate the influence of analgesia with nonselective COX-2 inhibitor dexketoprofen on the functional activity of immune cells in tumor excision murine model.

\section{Materials and Methods}

Animal model and surgery design. 50 males of C57/black mice weighting 18-22 g and 1.5 months old were used for this study. Mice were housed in an animal care facility of the National Cancer Institute, Ukraine. All procedures with animals were performed in accordance with the principles of humanity as it was written in "General principles of animal experimentation" approved by the National Congress on Bioethics (Kyiv, 2001-2007) and in accordance 
with Council directive of November 24, 1986 on the approximation of laws, regulations and administrative provisions of the Member States regarding the protection of animals used for experimental and other scientific purposes (86/609/EEC).

Lewis lung carcinoma (LLC) cell line was used as an experimental tumor model. LLC cells were kindly provided by the Bank of Cell Line of R. E. Kavetsky Institute of Experimental Pathology, Oncology and Radiobiology, NAS of Ukraine. LLC cells were transplanted subcutaneously into the right hind paw in the amount of $4 \times 10^{5}$ cells per mouse. After the tumor cells transplantation experimental animals were randomized by weight and assigned to 3 groups (15 animals per group): experimental group I (received for perioperative analgesia $10 \mathrm{mg} /$ $\mathrm{kg}$ of opioid drug omnopon), experimental group II (received for perioperative analgesia $20 \mathrm{mg} / \mathrm{kg}$ of NSAID dexketoprofen) and control group (received equivalent volume of saline instead of analgesics). 5 mice were used as intact control (without tumor transplantation, surgical intervention and drugs administration) to assess the physiological levels of studied parameters.

Surgical removal of tumor was performed on day 22 after inoculation. Mice were anesthetized by ketamine ( $25 \mathrm{mg} / \mathrm{kg}$ intraperitoneally), tumor paw was ligated and amputated on the level of knee joint. Analgesic drugs (or saline in control group) were injected intraperitoneally 30 minutes before the tumor excision and once a day for 3 days after the surgery.

Five mice per group were euthanized at 3 timepoints: before the surgery, day 1 and day 3 after surgery. The number and volume of lung metastatic lesions were measured and spleens were taken for the evaluation of cytokines genes expression and cytotoxic activity of splenocytes.

Gene Expression Analysis by Quantitative Real-Time RT-PCR. Spleens were soaked overnight in RNAlater solution (Ambion, USA) and kept frozen until use at $-70{ }^{\circ} \mathrm{C}$. Total RNA was extracted using Ribozol (Amplisens, Russian Federation). Concentration of purified RNA was determined by measuring the absorbance at $260 \mathrm{~nm}$ using Nanodrop 1000 (Thermo Scientific Inc, USA). cDNA was synthesized from $200 \mathrm{ng}$ total RNA in a $20 \mu \mathrm{l}$ reaction mixture using the High-Capacity cDNA Reverse Transcription Kit with RNase Inhibitor (Applied Biosystems, USA). Quantitative Real-time PCR was performed in a total volume of $25 \mu 1$ containing $5 \mu \mathrm{l}$ of cDNA, $12.5 \mu 12 \mathrm{X}$ Maxima SYBR Green qPCR
Master Mix (Thermo Scientific Inc, USA), $0.25 \mu \mathrm{M}$ of each specific forward and reverse primers on ABI Prism 7500 Sequence Detection System (Applied Biosystems, USA) using Software Version 2.0.1. The PCR cycling conditions included an initial denaturation at $50{ }^{\circ} \mathrm{C}(2 \mathrm{~min})$ and $95{ }^{\circ} \mathrm{C}(10 \mathrm{~min})$, followed by 40 cycles at $95^{\circ} \mathrm{C}(15 \mathrm{~s})$ and $60^{\circ} \mathrm{C}(1 \mathrm{~min})$. Meltcurve analysis was performed immediately after the amplification protocol to determine if nonspecific products were amplified. Results of PCR were quantified using delta ct method. The mRNA level was normalized to housekeeping gene glyceraldehyde 3-phosphate dehydrogenase (GAPDH) expression. Primers were designed using Primer Express Software v2.0 and synthesized by Assay-by-Design service (Applied Biosystems, USA): forward primer 5'-CAGCAACAACATAAGCGTCA-3' and reverse primer $5^{\prime}$ CCTCAAACTTGGCAATACTCA-3' for IFN- $\gamma$; forward primer $5^{\prime}$-CACTTGAGAGAGATCATCGGC-3' and reverse primer 5'-TGCGAAGCACCTTGGAAGCCC-3' for IL-4; forward primer 5'-TGGACAACATACTGCTAACC-3' and reverse primer 5'-GGATCATTTCCGATAAGGCT-3' for IL-10; forward primer 5'-ACACGGAATACAGGGCTTTCGATTCA-3' and reverse primer 5'-CTTGGGCTTGCGACCCAGTAGTA-3' for TGF $\beta$; forward primer $5^{\prime}$-GCCATCAACGACCCCTTCATT-3' and reverse primer 5'-GCTCCTGGAAGATGGTGATGG-3' for GAPDH.

Cytotoxic activity assay. Spleen was excised from mice and transferred to $5 \mathrm{ml}$ complete RPMI1640 medium. Tissue was homogenized, washed and resuspended in RPMI-1640 medium. Viable cells were counted using hemocytometer. Obtained splenocytes were used as an effector cells (EC). Mice lymphoma cell line OH-1 (kindly provided by the Bank of Cell Line of R. E. Kavetsky Institute of Experimental Pathology, Oncology and Radiobiology, NAS of Ukraine) was used as target cells (TC). TC were placed in a $96-$ well plate by $2 \times 10^{4}$ cells/ well in a volume of $0.1 \mathrm{ml}$, and EC were placed by $4 \times 10^{5}$ cells/well in a volume of $0.1 \mathrm{ml}$ at the TC/EC ratio of $1: 20$. After $12 \mathrm{~h}$ of incubation in the $5 \%$ $\mathrm{CO}_{2}$ atmosphere at $37{ }^{\circ} \mathrm{C}$ cells were transferred to cytometry tubes and stained with fluorochrome propidium iodid $(2.5 \mu \mathrm{g} / \mathrm{ml})$. Percentage of dead TC was evaluated by using FACSCalibur flow cytometer and CellQuest Pro software (Beckton Dickinson, USA).

Statistical analysis. Statistical analysis was performed by Statistica 10 (StatSoft Inc., USA). To determine data statistical significance for normal 
distribution we used Student's $t$-test; Mann Whitney test was used for comparison of two independent groups and Wilcoxon test - for comparison of two dependent groups for nonparametric data. The values of $P<0.05$ were considered as significant.

\section{Results and Discussion}

Surgical trauma is associated with excessive inflammatory response followed by a compensatory anti-inflammatory response syndrome that is primarily mediated by cells of the adaptive immune system and results in dramatic depression of cellmediated immunity [2, 4]. Cytokines are vital in the inflammation process, playing an important role in both strengthening and suppressing the inflammatory response. Several results have confirmed the relationship between operative technique and cytokine response. They underline the importance of cytokine network changes that can play a role in the quality of post-operative care [7]. IFN- $\gamma$ and IL-4 are the main cytokines that regulate the switch of immune response either toward cell-mediated (pro-inflammatory) Th-1 type or humoral (anti-inflammatory) Th-2 type.

We did not observe any significant changes in IL-4 gene expression level in the immune cells from tumor-bearing animals after tumor resection, as well as differences between these indices in tumor-bearing and intact mice. In contrast, IFN- $\gamma$ mRNA level was significantly lower $(P<0.05)$ in splenocytes of tumor-bearing mice as compared to intact animals (Fig. 1, A), but showed a tendency to increase in all study groups on day 1 after tumor excision, reaching the level of intact animals. Although, to day 3 after the surgery this dynamics remains only in the dexketoprofen treated mice, whereas in omnopon-treated animals as well as in control animals the level of IFN- $\gamma$ mRNA was significantly lower. Postoperative upregulation of IFN- $\gamma$ gene expression can be caused by the abrogation of tumor-induced immune suppression after removal of a malignant tissue. Post-surgical immune suppression is realized through several mechanisms, including the increase of $\mathrm{PGE}_{2}$ secretion by myeloid cells [8]. $\mathrm{PGE}_{2}$ has a negative effect on IFN- $\gamma$ expression and secretion by NK-cells [9].

In our study on day 3 after the surgery IFN- $\gamma$ mRNA level were significantly lowered in splenic cells of mice after surgery without analgesics compared to intact animals, while in dexketoprofen treated mice it remains on the intact level and was
2.4 times higher than in control mice $(P<0.02)$. In splenocytes of mice received opioid analgesia, IFN- $\gamma$ gene expression level was 1.7 times higher than in control group $(P<0.05)$ but still lower than that in dexketoprofen mice by $40 \%(P<0.03)$. These findings are consistent with the data obtained on cancer pain model, pointing that analgesia can prevent paininduced immune suppression and thus metastatic growth [10]. On the other hand, immunological benefits from pain relief could be diminished when opioid analgesics are used: in vitro studies have shown that morphine and other opioids can interfere with IFN- $\gamma$ promoter activity in immune cells through cAMP dependent signaling from opioid receptors [11]. Exerting a comparable analgesic effect, dexketoprofen lacks immunosuppressive properties of opioids. Furthermore, dexketoprofen inhibits synthesis of PGE2, which is known to augment IFN- $\gamma$ and other pro-inflammatory cytokines expression [12].

Anti-inflammatory cytokines, such as TGF- $\beta$ and IL-10, may aggravate surgical stress-induced immune suppression. As a pleiotropic cytokine, TGF- $\beta$ regulates various immune cell types including natural killer cells, myeloid cells, CD4+ and $\mathrm{CD} 8+\mathrm{T}$ cells, promotes generation of T-regulatory cells. These properties are essential for the maintenance of tissue homeostasis and self-tolerance, but are also involved in tumor immune evasion mechanisms [13]. Surgical trauma, pain and blood loss were shown to induce the increase of systemic levels of TGF- $\beta$ [8].

In current study, we observed a potent increase of TGF- $\beta$ mRNA level in splenocytes of tumorbearing mice after surgical procedure (Fig. $1, C$ ). In mice that were underwent tumor removal without analgesia on day 1 after the surgery TGF- $\beta$ gene expression level was elevated 8.7 times as compared to preoperative level $(P<0.05)$, while in mice, received analgesic drugs it was increased 4.5 and 4.8 times for omnopon and dexketoprofen group respectively (although in these groups it was not statistically significant, $P=0.06$ ). Differences in TGF- $\beta$ gene expression changes between control mice and those receiving analgesia in perioperative period may be due to the involvement of this cytokine in pain modulation during trauma and recovery. Thus, systemic administration of a TGF- $\beta$ neutralizing antibody was shown to enhance mechanical allodynia in mice after sciatic nerve injury [14], as well as modulate pain severity in $\lambda$-carrageenan-induced inflammation in rat model [15]. 

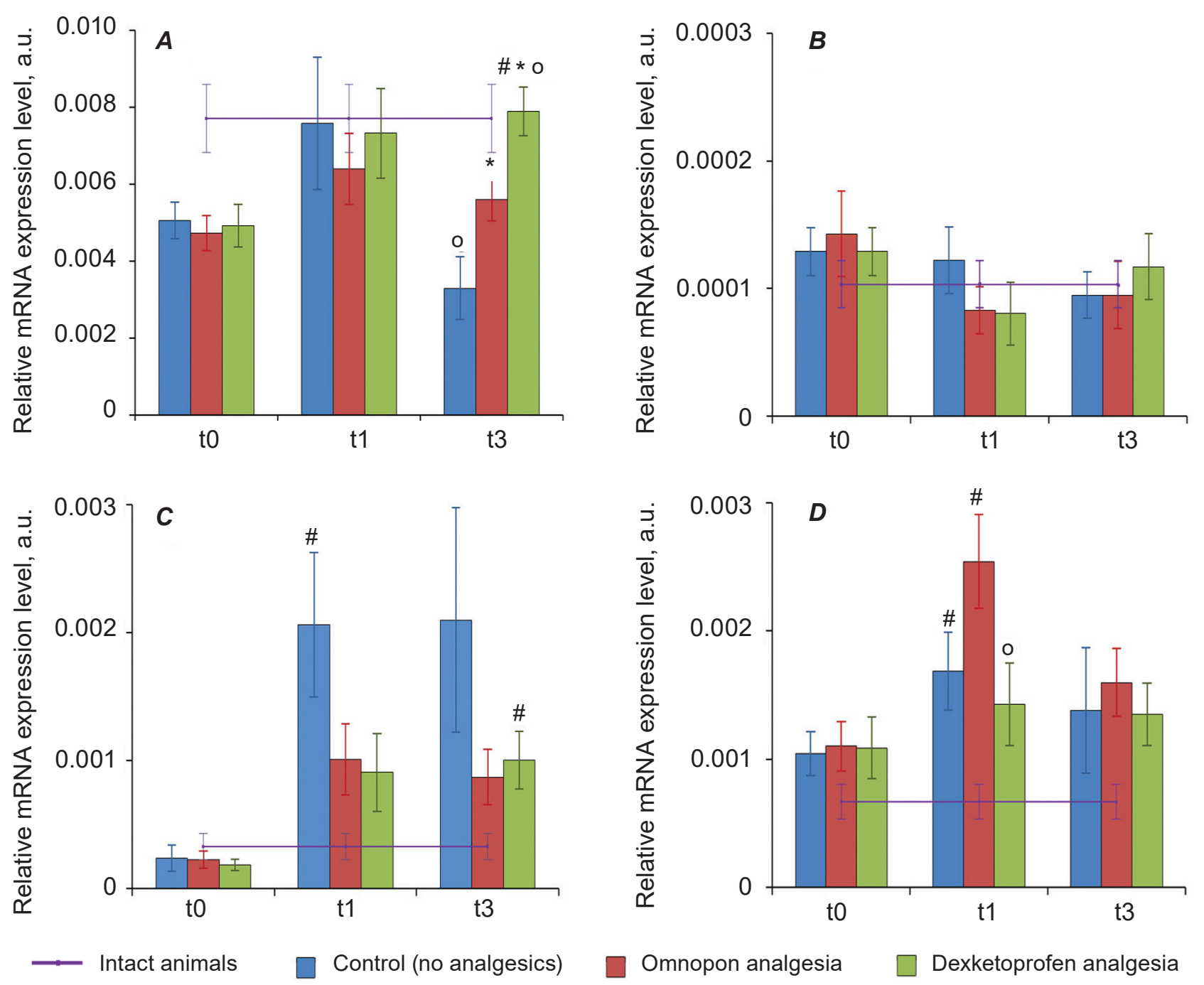

Fig. 1. Cytokines genes expression levels ( $a-I F N-\gamma, b-I L-4, c-T G F-\beta, d-I L-10)$ in splenocytes of tumorbearing mice before and after tumor resection: $t 0-1$ day before the surgery, $t 1-1$ day after, $t 3-3$ days after the surgery. Values are given as meam $\pm \operatorname{SEM}(n=5)$, a.u. - arbitrary units; ${ }^{\circ} P<0.05$ compared to omnopon group; ${ }^{*} P<0.05$ compared to control group; ${ }^{*} P<0.05$ compared to preoperative values

IL-10, together with TGF- $\beta$, was shown to play a role in surgically induced immunosuppression, attenuating pro-inflammatory cytokine production and reducing monocyte HLA-DR expression after major surgical trauma [8].

In current research, after the surgical tumor removal we observed a significant increase in IL10 gene expression in splenocytes of control mice and mice receiving omnopon analgesia, but not in dexketoprofen treated mice (Fig. 1,D). The highest mRNA level of IL-10 on day 1 after the surgery was observed in omnopon group, where it increased 2.3 times as compared to baseline values $(P<0.03)$, though on day 3 after the surgery it decreased. This is consistent with findings, that subcutaneous mor- phine or heroin administration in mice upregulates IL-10 expression in splenocytes with peak values 24 hours after the injection [16]. In contrast to omnopon and control group, immune cells of mice treated with dexketoprofen analgesia, showed no significant elevation of IL-10 mRNA level after the tumor excision. Inhibition of $\mathrm{PGE}_{2}$ synthesis by dexketoprofen can be a reason for this, as $\mathrm{PGE}_{2}$ is known to upregulate IL-10 secretion in murine immune cells [17].

Cell-mediated immune response is essential in the elimination of malignant cells. Cytotoxic effector cells, such as NK cells and CTL, are capable of recognizing and killing malignant cells, but in contrast to CTL, NK cells exert their function without prior sensitization or MHC restriction [18]. 


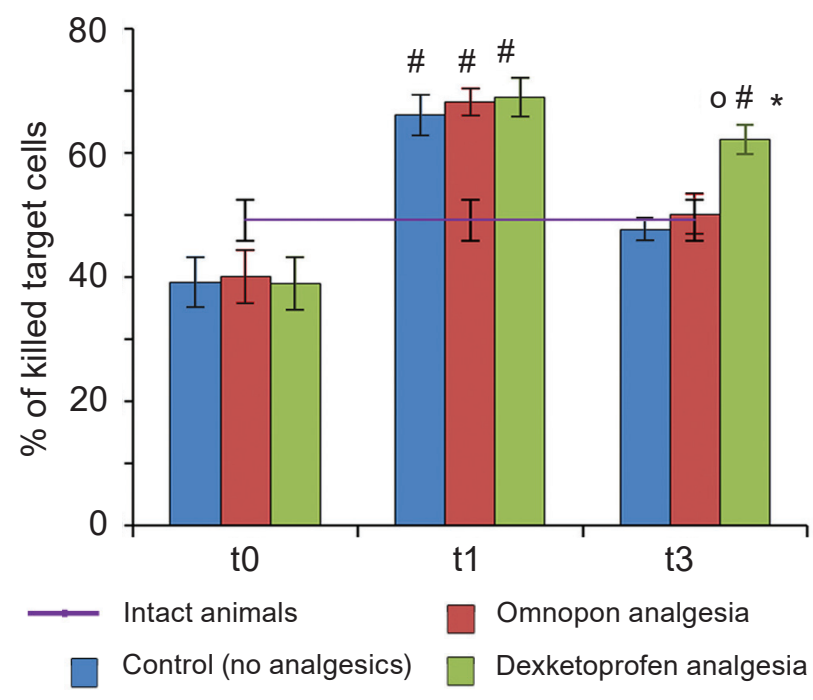

Fig. 2. Cytotoxic activity of splenocytes of tumorbearing mice against $\mathrm{OH}-1$ target cells before and after tumor resection: t0-1 day before the surgery, $t 1-1$ day after, $t 3-3$ days after the surgery. Values are given as meam $\pm S E M(n=5) ;{ }^{\circ} P<0.05$ compared to omnopon group; $* P<0.05$ compared to control group; ${ }^{\#} P<0.02$ compared to preoperative values

Functional activity of host NK cells is often compromised by tumor and can be additionally altered by analgesic and anesthetic drugs using during the surgery [19]. In current study, we measured cytotoxic activity (CA) of splenic immune effector cells of tumor-bearing mice against allogenic target cells (TC), so it represents mainly a cytotoxicity of splenic NK cells (Fig. 2).

A

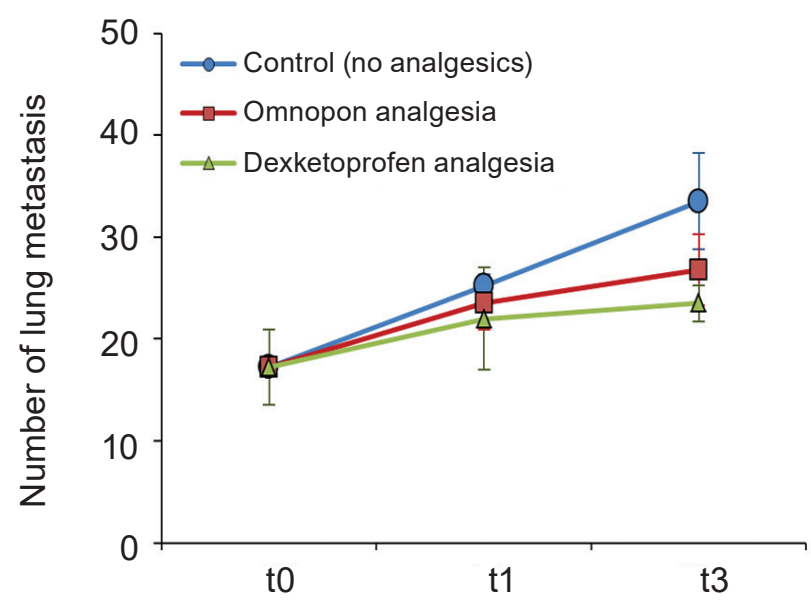

Splenocytes of tumor-bearing mice showed slightly reduced cytotoxic activity against $\mathrm{OH}-1 \mathrm{TC}$ as compared with intact animals $((39.5 \pm 4.1) \%$ vs $(49.2 \pm 3.2) \%, P=0.09)$. On day 1 after tumor removal cytotoxic activity increased significantly in all study groups as compared to values before the surgery $(P<0.05)$, though a subsequent decrease was observed. However, on day 3 after the surgery the highest level of splenocytes cytotoxicity retained in animals treated with COX-2 inhibitor dexketoprofen with mean values $(62.2 \pm 2.4) \%$ against $(50.2 \pm 3.3) \%$ in omnopon-treated mice and $(47.6 \pm 1.7) \%$ in control mice $(P<0.02)$. It has been reported, that $\mathrm{PGE}_{2}$ suppresses the cytolytic effector functions of NK cells, in a mechanism involving suppression of IL-2, and inhibits production of IFN- $\gamma$ by NK cells [20]. Furthermore, $\mathrm{PGE}_{2}$-mediated suppression of NK cell function during surgery has been shown to facilitate the establishment of metastases in experimental animals [21]. In current experimental model of tumor surgery we observed the escalation of metastases growth after primary tumor removal (Fig. 3).

The tendency to increase in the number and volume of metastases after tumor resection was more pronounced in control group than in animals received analgesics. On day 3 after the surgery mean volume of lung metastatic lesions in control group was $65.9 \pm 12.5 \mathrm{~mm}^{3}$ compared to $42.3 \pm 8.6 \mathrm{~mm}^{3}$ in omnopon group and $37.0 \pm 4.3 \mathrm{~mm}^{3}$, though these differences were not statistically significant. It is well known that surgical resection of primary tumor can trigger the growth of pre established distant metastases, and recent studies have shown that outcome

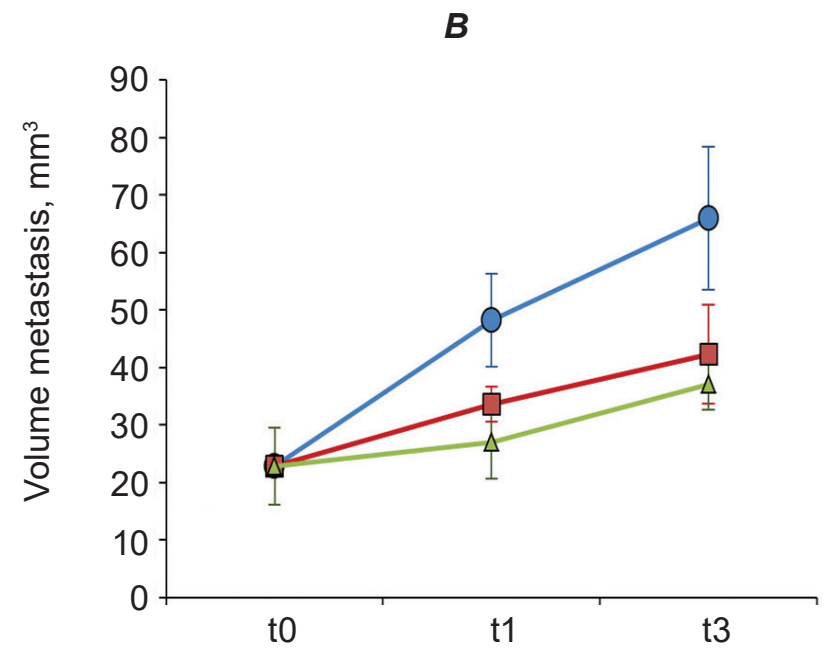

Fig. 3. Number (A) and volume (B) of lung metastasis before and after primary tumor resection: t0 - 1 day before the surgery, $t 1-1$ day after, $t 3$ - 3 days after the surgery. Values are given as meam $\pm S E M(n=5)$ 
of this process depends on functional activity of immune cells during perioperative period [4]. Although in our study perioperative analgesia with dexketoprofen results in higher postsurgical levels of IFN- $\gamma$ mRNA expression and NK cells cytotoxic activity compared to opioid analgesia, the absence of statistical differences in metastatic volume between these two groups could be due to the short observational time, and further researches targeted on long-term outcome could probably reveal more.

In summary, perioperative analgesia with cyclooxygenase inhibitor dexketoprofen in contrast to opioid analgesia with omnopon preserves higher functional activity of murine immune cells in the experimental model of tumor surgery, which is represented by higher natural killer cells cytotoxic activity and higher expression of IFN- $\gamma$ mRNA. Obtained data provides the basis for further researches of nonsteroidal anti-inflammatory drugs as a perspective alternative for opioid analgesia in cancer surgery.

\section{ВПЛИВ ЗНЕБОЛЮВАННЯ ОМНОПОНОМ ТА \\ ДЕКСКЕТОПРОФЕНОМ НА ФУНКЦІОНАЛЬНИЙ СТАН ІМУННИХ КЛІТИН МИШЕЙ НА МОДЕЛІ ХІРУ РГІЧНОГО ВИДАЛЕННЯ ПУХЛИНИ}

\section{Р. I. Сидор ${ }^{1,2}$, Н. М. Храновська О. В. Скачкова ${ }^{1}$, Л. М. Сківка}

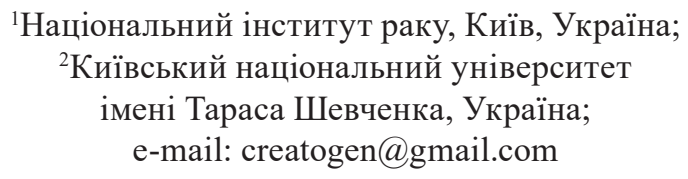

Досліджували вплив періопераційного знеболення неселективним інгібітором циклооксигенази-2 декскетопрофеном та опіоїдним аналгетиком омнопоном на функціональну активність імунних клітин мишей на моделі видалення перещепленої пухлини. Карциному легень Льюїс перещеплювали мишам лінії C57/black в задню лапу. На 23-тю добу пухлину видаляли хірургічно. Аналгетики вводили за 30 хв до та раз на добу протягом 3 діб після операції. Забір біологічного матеріалу проводили за добу до, на 1-шу та 3-тю добу після операції. Рівень експресії мPHK IFN- $\gamma$, IL-4, IL10 та TGF- $\beta$ в спленоцитах визначали методом кількісної ПЛР в режимі реального часу. Ци- тотоксичну активність спленоцитів оцінювали методом проточної цитометрії. Встановили, що рівень мРНК IL-10 зростав у 2,3 раза на 1 -шу добу після операції порівняно із доопераційним рівнем $(P<0,05)$ в спленоцитах мишей, які отримували опіоїдну аналгезію, тоді як у разі застосування декскетопрофену цей показник майже не змінювався. Рівень експресії мРНК IFN- $\gamma$ на 3-тю добу після операції був на $40 \%$ вищим у спленоцитах мишей, які отримували декскетопрофен порівняно 3 тими, що отримували омнопон $(P<0,05)$. Цитотоксична активність спленоцитів на 3-тю добу після операції становила $(62,2 \pm 2,4) \%$ за застосування декскетопрофену порівняно з $(50,2 \pm 3,3) \%$ за аналгезії омнопоном. У підсумку, після хірургічного видалення перещепленої пухлини функціональна активність клітин імунної системи мишей $є$ вищою у разі застосування аналгезії декскетопрофеном, ніж за застосування омнопону.

К л ючов і слов а: омнопон, декскетопрофен, інгібітор циклооксигенази-2, імунні клітини, видалення пухлини.

\section{ВЛИЯНИЕ ОБЕЗБОЛИВАНИЯ ОМНОПОНОМ И ДЕКСКЕТОПРОФЕНОМ НА ФУНКЦИОНАЛЬНОЕ СОСТОЯНИЕ ИММУННЫХ КЛЕТОК МЫШЕЙ НА МОДЕЛИ ХИРУРГИЧЕСКОГО УДАЛЕНИЯ ОПУХОЛИ}

\section{Р. И. Сидор ${ }^{l, 2}$, Н. Н. Храновская ${ }^{l}$, \\ О. В. Скачкова ${ }^{1}$, Л. М. Скивка}
'Национальный институт рака, Киев, Украина; ${ }^{2}$ Киевский национальный университет имени Тараса Шевченка, Украина; e-mail: creatogen@gmail.com

Изучали влияние периоперационной аналгезии с использованием неселективного ингибитора циклооксигеназы-2 декскетопрофена и опиоидного аналгетика омнопона на функциональную активность иммунных клеток мышей на модели хирургического удаления перевитой опухоли. Карциному легких Льюис перевивали мышам линии C57/black в заднюю лапу. На 23-ьи сутки опухоль удаляли хирургически. Аналгетики вводили за 30 мин до и раз в сутки в течение 3 дней после операции. Забор биологического материала проводили за сутки до, на 
1-е и 3-ьи сутки после операции. Уровень экспрессии мРНК IFN- $\gamma$, IL- 4 , IL-10 и TGF- $\beta$ в спленоцитах определяли методом количественной ПЦР в режиме реального времени. Цитотоксическую активность спленоцитов оценивали методом проточной цитометрии. Установлено, что в спленоцитах мышей, получавших опиоидную аналгезию, уровень мРНК IL-10 увеличивался в 2,3 раза на 1-е сутки после операции по сравнению с дооперационным уровнем $(P<0,05)$, тогда как при аналгезии декскетопрофеном этот показатель почти не изменялся. Уровень экспрессии мРНК IFN- $\gamma$ на 3-ьи сутки после операции был на 40\% выше в спленоцитах мышей, получавших декскетопрофен по сравнению с теми, которые получали омнопон $(P<0,05)$. Цитотоксическая активность спленоцитов на 3 -ьи сутки после операции составляла $(62,2 \pm 2,4) \%$ при применении декскетопрофена по сравнению c $(50,2 \pm 3,3) \%$ при аналгезии омнопоном. Таким образом, после хирургического удаления перевитой опухоли функциональная активность клеток иммунной системы мышей выше при применении аналгезии декскетопрофеном, чем при применении омнопона.

К л ю че вы е с л о в а: омнопон, декскетопрофен, ингибитор циклооксигеназы-2, иммунные клетки, удаление опухоли.

\section{References}

1. Das J, Kumar S, Khanna S, Mehta Y. Are we causing the recurrence-impact of perioperative period on long-term cancer prognosis: Review of current evidence and practice. $J$ Anaesthesiol Clin Pharmacol. 2014; 30(2): 153-159.

2. Kimura F, Shimizu H, Yoshidome H, Ohtsuka M, Miyazaki M. Immunosuppression following surgical and traumatic injury. Surg Today. 2010; 40(9): 793-808.

3. Meserve JR, Kaye AD, Prabhakar A, Urman RD. The role of analgesics in cancer propagation. Best Pract Res Clin Anaesthesiol. 2014; 28(2): 139-151.

4. Kaye AD, Patel N, Bueno FR, Hymel B, Vadivelu N, Kodumudi G, Urman RD. Effect of opiates, anesthetic techniques, and other perioperative factors on surgical cancer patients. Ochsner J. 2014; 14(2): 216-228.

5. Yiannakopoulou E. Targeting epigenetic mechanisms and microRNAs by aspirin and other non steroidal anti-inflammatory agents - implications for cancer treatment and chemoprevention. Cell Oncol (Dordr). 2014; 37(3): 167-178.

6. Harris RE. Cyclooxygenase-2 (cox-2) blockade in the chemoprevention of cancers of the colon, breast, prostate, and lung. Inflammopharmacology. 2009; 17(2): 55-67.

7. Lisowska B, Szymańska M, Nowacka E, Olszewska M. Anesthesiology and the cytokine network. Postepy Hig Med Dosw (Online). 2013; 67: 761-769.

8. Menger MD, Vollmar B. Surgical trauma: hyperinflammation versus immunosuppression? Langenbecks Arch Surg. 2004; 389(6): 475-484.

9. Van Elssen $\mathrm{CH}$, Vanderlocht $\mathrm{J}$, Oth $\mathrm{T}$, Senden-Gijsbers BL, Germeraad WT, Bos GM. Inflammation-restraining effects of prostaglandin E2 on natural killer-dendritic cell (NK-DC) interaction are imprinted during DC maturation. Blood. 2011; 118(9): 2473-2482.

10. Sasamura T, Nakamura S, Iida Y, Fujii H, Murata J, Saiki I, Nojima H, Kuraishi Y. Morphine analgesia suppresses tumor growth and metastasis in a mouse model of cancer pain produced by orthotopic tumor inoculation. Eur $J$ Pharmacol. 2002; 441(3): 185-191.

11. Ninković J, Roy S. Role of the mu-opioid receptor in opioid modulation of immune function. Amino Acids. 2013; 45(1): 9-24.

12. Jiang J, Dingledine R. Prostaglandin receptor EP2 in the crosshairs of anti-inflammation, anticancer, and neuroprotection. Trends Pharmacol Sci. 2013; 34(7): 413-423.

13. Gu AD, Zhang S, Wang Y, Xiong H, Curtis TA, Wan YY. A critical role for transcription factor Smad4 in T cell function that is independent of transforming growth factor $\beta$ receptor signaling. Immunity. 2015; 42(1): 68-79.

14. Lantero A, Tramullas M, Díaz A, Hurlé MA. Transforming growth factor- $\beta$ in normal nociceptive processing and pathological pain models. Mol Neurobiol. 2012; 45(1): 76-86.

15. Ronaldson PT, Finch JD, Demarco KM, Quigley $\mathrm{CE}$, Davis TP. Inflammatory pain signals an increase in functional expression of organic anion transporting polypeptide 1a4 at the bloodbrain barrier. J Pharmacol Exp Ther. 2011; 336(3): 827-839.

16. Pacifici R, di Carlo S, Bacosi A, Pichini S, Zuccaro P. Pharmacokinetics and cytokine 
production in heroin and morphine-treated mice. Int J Immunopharmacol. 2000; 22(8): 603-614.

17. Edwards JP, Emens LA. The multikinase inhibitor sorafenib reverses the suppression of IL-12 and enhancement of IL-10 by PGE in murine macrophages. Int Immunopharmacol. 2010; 10(10): 1220-1228.

18. Gutkin DW, Shurin MR. Clinical evaluation of systemic and local immune responses in cancer: time for integration. Cancer Immunol Immunother. 2014; 63(1): 45-57.

19. Forget P, De Kock M. Could anaesthesia, analgesia and sympathetic modulation affect neoplasic recurrence after surgery? A systematic review centred over the modulation of natural killer cells activity. Ann Fr Anesth Reanim. 2009; 28(9): 751-768.

20. Walker W, Rotondo D. Prostaglandin E2 is a potent regulator of interleukin-12- and interleukin-18induced natural killer cell interferon-gamma synthesis. Immunology. 2004; 111(3): 298-305.

21. Yakar I, Melamed R, Shakhar G, Shakhar K, Rosenne E, Abudarham N, Page GG, BenEliyahu S. Prostaglandin e(2) suppresses NK activity in vivo and promotes postoperative tumor metastasis in rats. Ann Surg Oncol. 2003; 10(4): 469-479.

Received 27.05.2016 